りの応力と力を解析的に求め，これによって限界絞り 比,加工效溹など具体的に論じたものである.初期の工 程では曲げと絞りの混ったものであるが，ついに純粋 絞りの工程に達する。この範围を瞬閏絞り比 $\beta=\frac{D}{d_{0}}$ できめ，絞り力が最高になる $\beta_{t}$ を応力解析で求めた ものと比較して無験とよい一致を示して抒り，最高荷

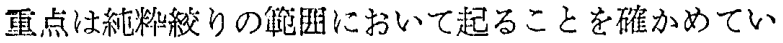
る. また店力計算加方最商絞り応力 $\sigma_{z \max }=P_{\max } /$

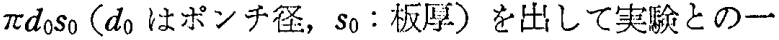
致から $\beta_{t}$ の棓平価の正しいことを舆付けている. $\mu=0$

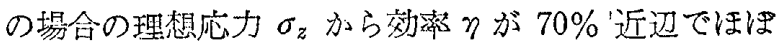
一定であり，また， $\beta_{0 \max }$ の加工限界については $\sigma_{z \max }$ が素材の弓張强さ $\left[\sigma_{B}=a\left(\frac{n}{c}\right)^{n}\right.$ として に等しいと して限界值を $\beta_{0 \max }=2.85 \sim 2.95$ としている.これ も実際とよく一致する，応力解法からこれらの諸加工 性を表現したが，論文には詳細な応力分布などの計算 がないのが物足りない感じがする。【葉山益次郎]

621.983 .4

†[364] Bohner \& Koehle P 1116 形フローターニ ング成形機 [K.W. Hards, Metalworking Product, 1961-6, Vol. 105, No. 23, p. 71 73, 図 6] Oldbury の Acme Spinning Co. が表記の機械を倫えつけてよ り約 1 年間にわたってのフローターニングの成果の一 端が紹介されている。

この成形機の慾量は，ブランク直埾 $60 \mathrm{in}$, 製品深さ $40 \mathrm{in}$, 板厚 $11 / 16$ in (アルミニウム), 19/32 in (銅), $5 / 16$ in (軟鋼)，5/32 in (ステンレス鋼) で，液圧に より，装着された型板にならって動く成形ローラによ り加工が進められる.したがって，加工力の大小とは 無関係に，製品を設計された壁厚に仕上げることがで き, ローラ押付力は液圧によるので, 調整操作が軽い という利点を有する。

本文には，アルミニウム，ステンレスなどを材料を し, じょうごなど, 工程中に通常のスピニング操作を 含むものを交えて数例が簡単に示されている。おもに 工具設計上の開発がなされたが，まだ試行錯愦的なと ころもあり，また製作個数が50以下でも採算はとれ るが，数百個を量産するのが望ましいと述べている。

[堤成晃]

\section{$620.177: 677.017$}

†[365]織物のしわ回復試験 [S.L. Anderson \& G.E. Settle, J. Text. Inst., 1961-6, Vol. 52, No. 6, p. T 298〜 T 299, 図 1] 現在実施されている しわ回復性の試駼は BS 3086：1959 に規定のように， 比較的細辰い試験片について，しわ付を実施して回復 角を求めるが，この場合試験片の腕に重力による曲げ

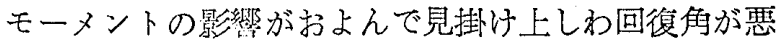
く現われ，特に莎地の織物では，その影響が大きく， 測定操作を困醮になる。

この点を改良するためい長さ $1.75 \mathrm{~cm} \times$ 幅 $2.54 \mathrm{~cm}$ の試験片を作り，短片を二つ折をなして，しわ付を与え た後，平面上に試験片を山形になるように放置して， しわ回復させ投影器による写像をもってしわ回復角を 測定する。しわ付㭙聞之荷重を厳しくして試鈳を行な ったところ，BS 規定の方法よりも，試料間の差異を
第 14 表 測定結果（しわ回復角の平均）

\begin{tabular}{cc|c|cc}
\hline \hline 陚 & 料 & BS $3086: 1959$ & C & 方 \\
\hline 羊 毛 法 \\
"蟣
\end{tabular}

良く判別できた。

〔吉田
穔]

620.178.16:677.017

†[366]同し布の間の稀擦係数の測定 [G.H. Thorndike \& L. Varley, J. Text. Inst., Proceedings, 1961-6, Vol, 52, No. 6, p. 255 271, 図 9, 表 3] 有相互の摩擦係数测定機を試作し，検討を加えた。 水平に張られた試料は上下に重ねられ，上側の布はば ねで弓かれている，下側の布は，任意の速度で往復運 動をする.耐者の摩擦の大きさだけげねが伸縮し，こ れと連結したペンが伸縮量を記録紙上に描く．正逆两 方向の静摩擦係数が連続的に求められ，また上下試料 の経糸方向の傾斜角を自由に選定できる.

6 種類の試料について測定した結果を従来の傾斜板 法の結果と此較したところ，絶対値は 10〜20\% ほど 新形機の力が大きく，順位は半分ほど一致しなかっ た。手ざわりの順位とは新形機が完全に一致した。さ らに試料の組成の影瀶は，静摩擦係数の值が，上下試 料の経系方向が平行に近いほど小さいことと浮き糸が 多い組織ほど小さいこと，ハイドラフトそ毛系は小さ いこと，水分率が高いほど $\mathrm{pH}$ が小さいほど小さいこ と学知った。

[風閭健]

\subsection{7:677.017}

†[367]瀻維のねじれ特性比較用バイブロスコープ

[P. Nordon, J. Sci. Instr., 1961-9, Vol. 38, No. 9, p. 349〜351, 図 4] 1〜200 サイクルの範国で, 細 い織維に，强制ねじれ振動を与え，動的ねじれ性質を， 測定する装置を作った。装置は，密閉でき，温湿度調 節が，容易にできるので，特に温湿度の変化により， 機械的性質の変化する試料に対し, 有効である。コイ ルの中に，0.5〜1 $\mathrm{g}$ のおもりをつけた試料をつるし， 試料の中央に小さい磁石を取付ける、コイルに交流を 流し，磁場の振動により，磁不に，ねじれ振動を起さ せる. 試料の振動は, 磁石に光線を当て, その影を, フォトトランジスタで検出，検出された試料の振動 を，陰極線オシロスコープのY軸へ，コイルの入力を X軸へ加え，リサージ二図形を措かせて解析する。こ のため精度が良く，周波数で $0.1 \%$ ，減昰定数で，1〜 $3 \%$ である，本来，比較測定しかできないが，性彉既 知の試料により，較正をすれに゙，絶効的测定にも使用 できる。 [柏睮孟]

\section{$539.31: 677.017: 681.142 .004$}

$\dagger[368]$ 繊維, 糸, 織物の応力一ひずみのデータの自 動処理に用いられる計算機 [W.J. Thorsen, Text. Res. J., 1960-11, Vol. 30, No. 11, p. 827 835]

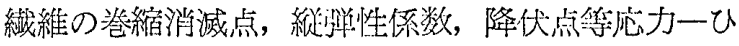
ずみ曲線のパラメータは応力ーいずみ曲線の二次, 三 次の街分によって求めることがでさる。微分を行なう ためアナグロ計算機を用いた。そのおもな湍算琶素は 抵抗と容量のフィードバック回路をもった值流堌幅器 である.使用装置はおの㧈のの 10 個のプラグイン式 演算增幅器を内蔵する 2 台の自動計算機マニホルドを 